GENDER AND THE MODERN RESEARCH UNIVERSITY 



\section{Gender and the Modern Research University}

THE ADMISSION OF WOMEN TO GERMAN HIGHER EDUCATION, I865-I9I 4

Patricia M. Mazón

STANFORD UNIVERSITY PRESS

STANFORD, CALIFORNIA

2003 
Stanford University Press

Stanford, California

(C) 2003 by the Board of Trustees of the

Leland Stanford Junior University. All rights reserved.

Library of Congress Cataloging-in-Publication Data

Mazón, Patricia M.

Gender and the modern research university : the admission of women to German higher education, 1865-1914 / Patricia M. Mazón.

p. cm.

Includes bibliographical references and index.

ISBN 0-8047-464 I-9 (alk. paper)

I. Women-Education (Higher)-Germany-History. 2. Universities and colleges-Germany-Admission-History. 3. Sex discrimination in higher education-Germany-History. I. Title.

LC2 I06.M39 2003

$378.1^{\prime} 9822-\mathrm{dc} 2 \mathrm{I}$

2003005980

Original Printing 2003

Last figure below indicates year of this printing:

$\begin{array}{llllllllll}12 & \text { II } & 10 & 09 & 08 & 07 & 06 & 05 & 04 & 03\end{array}$

Typeset by Classic Typography in 10/12.5 Sabon 
For my mother, Mary Medina Mazón,

and in memory of my grandmother,

Maria Inés Garaygordóbil Medina (I92 I-1979) 
